\title{
KARAKTERISTIK OSEANOGRAFI PADA DAERAH PENANGKAPAN IKAN TUNA DI SAMUDERA HINDIA BAGIAN TIMUR INDONESIA
}

\section{Oceanography Characteristics On Tuna Fishing Ground Area In Eastern Indian Ocean Of Indonesia}

\author{
La Demi $^{1}$, A.Tupamahu ${ }^{2}$, HJD Waas ${ }^{3}$, Deni Sarianto ${ }^{4 *}$, Rangga Bayu Kusuma Haris ${ }^{5}$ \\ Sekolah Usaha Perikanan Kementrian Kelautan ${ }^{1}$ \\ Dosen Program Studi Pemanfaatan Sumberdaya Perairan Universitas Pattimura Ambon ${ }^{2}$ \\ Dosen Program Studi Ilmu Kelautan Universitas Pattimura Ambon ${ }^{3}$ \\ Dosen Program Studi Perikanan Tangkap Politeknik KP Maluku ${ }^{4}$ \\ Dosen Program Studi Perikanan Tangkap Politeknik KP Dumai ${ }^{5}$ \\ *Corresponding author : Denisarianto45@gmail.com
}

\begin{abstract}
ABSTRAK
Ikan tuna merupakan ikan ekomomis penting. Daerah penangkapan tersebar luas di lima Samudera. Penelitian bertujuan mendeterminasi karakteristik oseanografi perairan Samudera Hindia bagian timur kaitannya dengan daerah penangkapan armada tuna long line dan fiture oseanografi tertentu yang dapat digunakan sebagai indikator penciri daerah potensial penangkapan tuna menggunakan pencitraan satelit oseanografi. Daerah penangkapan armada tuna long line Indonesia dan Jepang pada tahun 2017 terkonsentrasi pada $11^{\circ}$ sampai $15^{\circ}$ Lintang Selatan dan $113^{\circ}$ sampai $120^{\circ}$ Bujur Timur. Terkonsentrasi daerah penangkapkan dibuktikan hasil pengamatan menggunakan global fishing watch. Selain itu terjadinya upwelling yang dibuktikan dengan tingginya klorofil- a dan rendahnya SPL pada bulan Juli Agustus serta kenaikan paras laut dan edies pada bulan Agustus hingga Oktober. Faktor perubahan musim memberikan pengaruh yang besar terhadap sebaran daerah penangkapan di samudera bagian timur Indonesia.
\end{abstract}

Kata kunci: Tuna, Klorofil-a, SPL

\begin{abstract}
Tuna is a fish improved economic important. the fishing ground is widespread in the five Oceans. Research aimed at determining the characteristics of the oceanographic waters of the Indian Ocean in the eastern part of the relation to the fishing ground the fleet of tuna long line and fiture oceanography specific that can be used as an indicator of identifying areas of potential tuna fishing using satellite imaging, oceanographic. fishing ground the fleet of tuna long line Indonesia and Japan in the year 2017 concentrated on the $11^{\circ}$ to $15^{\circ}$ South Latitude and $113^{\circ}$ to $120^{\circ}$ East Longitude. Concentrated fishing ground evidenced the results of observations using the global fishing watch. In addition, the occurrence of upwelling as evidenced by the high chlorophyll - a and low SST in July - August as well as the rise paras the sea and the edies in August to October. Factor change of the season gives a great influence on the distribution of fishing ground in the ocean the eastern part of Indonesia.
\end{abstract}

Keywords: Tuna,Chlorophyll-a, SPL 


\section{PENDAHULUAN}

Perairan Samudera Hindia bagian timur termasuk Wilayah Pengelolaan Perikanan (WPP) 573 merupakan daerah potensial penangkapan tuna terutama oleh armada penangkapan tuna long line dan purse seine nasional maupun Asing. Kawasan perairan ini merupakan bagian dari wilayah pengelolaan Indian Ocean Tuna Commision (IOTC) dan Commision for the Conservation of Southern Bluefin Tuna (CCSBT) (KEPMEN-KP, 2015).

Besarnya potensi sumber daya tuna yang diestimasi dalam bentuk produksi maksimum lestari (Maximum Sustainable Yield/MSY) mengacu pada Regional Fisheries Mangement Organization (RFMO) termasuk WPP 571 dan WPP 572 diperkirakan produksi tuna mata besar (Thunnus obesus), madidihang (Thunnus albacares)), cakalang (Katsuwonus pelamis)), albacora (Thunnus alalunga) masing-masing sebesar 132000 ton/tahun, 344000 ton/tahun, 478000 ton/tahun dan 37082 ton/tahun. Sementara tuna sirip biru selatan (Thunnus maccuyi) yang hanya ditemukan pada WPP 573 diestimasi sebesar 14647 ton/tahun.

Kehadiran tuna di perairan ini didukung oleh kondisi oseanografi yang sesuai sehingga perairan mampu menopang dan mempertahankan keberlangsungan perikanan komersil. Penelitian hubungan antara kondisi oseanografi perairan dengan keberadaan tuna sejauh ini telah dilakukan oleh (Bahri et al., 2017) dan (Sarianto, 2018) menggunakan satelit oseanografi namun hanya menggunakan parameter Sea Surface Hight Anomali. Di lain sisi, kajian karakteristik oseanografi perairan telah dilakukan oleh (Gaol and Sadhotomo, 2017) namun data yang digunakan merupakan gabungan data sekunder hasil penelitian sebelumnya sehingga tidak mewakili kondisi perairan di mana aktivitas penangkapan berlangsung.

Pengetahuan tentang tentang kondisi oseanografi perairan dan kualitas penting diketahui terutama dalam upaya meningkatkan keberhasilan penangkapan dan penentuan daerah potensial penangkapan sehingga menghemat waktu dan biaya operasional armada (Sarianto et al., 2017). Seiring dengan kemajuan teknologi remote sensing multi sensor satelit, Argo Drifter yang kontinyu menyediakan data oseanografi permukaan dan kolom perairan dan tersedianya data in situ lokasi penangkapan tuna via Global Fishing Watch maka karakteristik oseanografi daerah potensial penangkapan tuna di perairan timur samudera Hindia dapat dikaji.

Penelitian ini bertujuan

Mendeterminasi karakteristik oseanografi perairan timur Samudera Hindia termasuk WPP 573 dalam kaitannya dengan daerah penangkapan armada tuna long line. (2) Mendeterminasi fiture oseanografi tertentu yang dapat digunakan sebagai indikator penciri daerah potensial penangkapan tuna menggunakan pencitraan satelit oseanografi.

Penelitian ini diharapkan menjadi bagian dari metode analisis daerah fishing ground tuna di perairan sehingga dapat dimanfaatkan untuk eksploitasi sumber daya tersebut secara optimal.

\section{METODOLOGI}

\section{Lokasi dan Waktu Penelitian}

Penelitian ini telah dilaksanakan selama bulan Juni - September 2019 yang difokuskan pada perairan timur Samudera Hindia termasuk WPP 573. Daerah penelitian dibatasi pada koordinat geografis $6-15^{\circ} \mathrm{S} ; 104-124^{\circ} \mathrm{E}$ dengan luas 
diperkirakan sebesar $540 \mathrm{mil}^{2}$. Perolehan dan pengolahan data dilakukan pada
Laboratorium Multi Media FPIK Unpatti (Lihat Gambar 1).

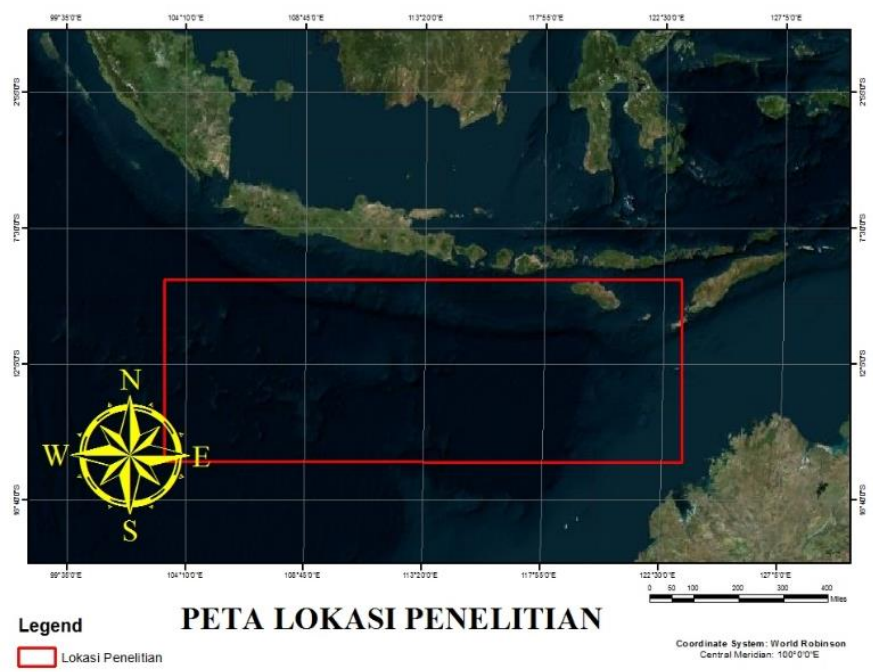

Gambar 1. Peta lokasi Penelitian

\section{Metode Penelitian}

Metode yang digunakan dalam penelitian ini adalah metode eksploratif yaitu penelitian yang bertujuan untuk menggali secara luas tentang sebab-sebab atau hal-hal yang mempengaruhi terjadinya sesuatu. Mengembangkan teori yang bersifat tenta-tif, membuka kemungkinan akan diadakannya penelitian lanjutan terhadap topik yang dibahas, serta menentukan teknik dan arah yang akan digunakan dalam penelitian berikutnya (Arikunto, 2019).

Pencuplikan data fisik dan biologi oseanografi lainnya dilakukan melalui hasil penyiaman secara sinoptik satelit oseanografi seperti SPL, SSHA dan klorofil-a diperoleh melalui ERDDAP (Schweitzer et al., 2018). Pencuplikan data in situ kondisi fisik oseanografi perairan seperti suhu perairan dan derivatifnya seperti kedalaman lapisan nutriklin dan termoklin dilakukan melalui software Marine Argo Atlas yang terhubung dengan Argo data center melalui koneksi internet. Data suhu perairan yang direkam oleh Argo
Drifter dan diakses secara online melalui perangkat lunak Argo Marine Atlas (altimetry.fr). Sementara pencuplikan data lokasi penangkapan tuna dan armada tuna long line Indonesia dan Jepang diperairan timur samudera Hindia dan WPP 573 selama tahun 2017 dilakukan melalui global fishing watch.

Pencuplikan parameter di atas dimaksudkan untuk analisis variabilitas daerah penangkapan tuna dalam kaitannya dengan fenomena oseanografi tertentu seperti front termal, mesoscale eddies, upwelling dan gelombang internal.

Fenomena menarik dari taikan mengacu pada sintesa hasil penelitian sebelumnya menunjukkan bahwa gangguan dalam skala yang luas diperairan pada interface antara lapisan homogen dan lapisan termoklin dapat menyebabkan terangkatnya kedalaman klorofil maksimum (Deep Chlorophyl Maximum/ DCM) terangkat kedalam lapisan homogen sehingga meningkatkan kesuburan lapisan permukaan. Mekanisme ini hanya dapat terjadi sebagai akibat gangguan gelombang 
dalam (internal wave/IW). Di lain sisi gelombang, lapisan homogen dan isoterm $20^{\circ} \mathrm{C}$ akan ditenggelamkan lebih dalam dan hal ini bersesuaian dengan lembah gelombang.

Hasil sintesa penelitian sebelumnya menunjukkan bahwa ada relasi antara suatu kejadian fenomena oseanografi dengan fenomena lainnya di perairan. Eddies, termal front, zona konvergen dan divergen merupakan fiture utama yang biasanya berperan sebagai oase di perairan dan digunakan sebagai indikator daerah fishing ground tuna di perairan (Acha et al., 2015; Laurs et al., 1984) . Fiture ini dapat dideteksi melalui citra SPL, SLA atau SSHA, Arus geostropikdan ocean color.

Pencuplikan parameter kimia perairan seperti nitrat dan oksigen dalam kolom perairan dilakukan menggunakan data Levitus klimatologi yang diperoleh melalui website https://iridl.ldeo.columbia.edu/. Penggunaan parameter ini dimaksudkan untuk menganalisa keberadaan tuna pada kondisi oksigen dan kandungan nitrat tertentu untuk setiap spesies tuna. Distribusi vertikal nitrat dan suhu perairan dapat menerangkan fenomena gangguan dalam kolom air yang mempengaruhi variabilitas swimming layer tuna seperti IW di mana efek rototiler gelombang berasosiasi dengan kedalaman penebaran alat tangkap longline.

\section{Analisis Data}

Analisa data dilakukan terhadap beberapa parameter oseanografi meliputi :

\section{Suhu Permukaan Laut (SPL)}

Analisa terhadap distribusi vertikal SPL dilakukan pada range kedalaman 0-500 $m$ yang diasumsikan sebagai kedalaman maksimum distribusi tuna di perairan menggunakan data yang dikoleksi oleh
Argo drifter dengan bantuan perangkat lunak Global Marine Atlas. Distribusi vertikal suhu air laut dibuat dengan menarik garis transek vertikal garis pantai melewati batas WPP 573 menuju perairan laut lepas. Analisis dilakukan terhadap variabilitas isoterm $20^{\circ} \mathrm{C}$ dan suhu pada swimming layer spesies tuna yang berbeda berdasarkan data swimming layer hasil sintesa penelitian sebelumnya.

\section{Sea Level Anomaly (SLA)}

Pengaruh gelombang internal (IW) terhadap distribusi daerah penangkapan tuna dianalisis menggunakan pola sebaran vertikal suhu air dan konsentrasi nitrat pada range kedalaman $0-500 \mathrm{~m}$ (Krauss and Bricker 1967). Keberadaan IW juga dideteksi melalui distribusi vertikal ketinggian dinamik permukaan perairan pada transek horisontal yang sama. Kehadirannya juga divalidasi dengan data citra satelit SSHA/SLA dan ocean color.

\section{Klorofil-a}

Identifikasi kedalaman nitracline yaitu lapisan kaya nitrat dan proses biologi aktif dan mewakili batas terendah lapisan di mana nitrat diasumsikan sangat terbatas (Le Bouteiller et al., 1992) menggunakan isoplet $1,0 \mu \mathrm{M} / \mathrm{l}$. Kedalaman isoplet tersebut juga berasosiasi dengan kedalaman klorofil-a maksimum (Deep Chlorophyl Maximum/DCM) (Mackey 1995) yang juga berasosiasi dengan range suhu $26-27^{\circ} \mathrm{C}$.

Kontribusi GI melalui pengangkatan DCM dihitung melalui nilai persen variance flourisensi fitoplankton pada kedalaman integrasi zona kedalaman optikal satelit MODIS Sugiyono 2017 dalam (Sarianto 2018) dengan formula :

$S^{2}(\%)=\frac{S^{2}}{\Sigma S^{2}} x 100$ dan $S^{2}=\frac{\Sigma y^{2}-\frac{(\Sigma y)^{2}}{n}}{n-1}$ 
Keterangan :

$\mathrm{S}^{2}$ : nilai variance flourisensi fitoplankton pada transek

$\mathrm{n}$ : jumlah data

y : flourisensi fitoplankton $\left(\mathrm{mg} / \mathrm{m}^{3}\right)$

\section{Daerah Penagkapan Ikan}

Analisis keberadaan daerah penangkapan tuna dengan fitur oseanografi tertentu seperti termal front, front klorofila, area upwelling (umbalan), divergen dan konvergen arus dilakukan dengan melakukan overlay lokasi penangkapan tuna dengan citra SPL, SLA/ SSHA, geostropik current, dan ocean color pada perangkat lunak ArcGis.

\section{HASIL DAN PEMBAHASAN}

\section{Karakteristik Oseonografi Perairan Samudera Hindia Bagian Timur.}

\section{Klorofil-a}

Hasil analisa sepanjang tahun 2017 perairan Samudera Hindia bagian Timur dan sekitarnya rata-rata bulanan menunjukan bahwa secara umum konsentrasi klorofil-a berkisar antara $0.04-$ $0.9 \mathrm{mg} / \mathrm{m}^{3}$. Secara temporal puncak konsentrasi klorofil-a tinggi dimulai dari bulan Maret sampai dengan November dengan puncak tertinggi pada bulan Agustus. Data distibusi klrofil - a di sajikan pada Gambar 1.

Tingginya konsentrasi klorofil - a pada bulan Agustus diakibatkan bertiupnya angin timur pada bulan Juni dan Juli sehingga terjadinya naiknya masa air dari dasar ke permukaan terutama pada pesisir pulau dan terbawa oleh arus ke laut lepas. Sedangkan (Kunarso et al., 2011) menyatakan klorofil tertinggi di samudera bagian Jawa dikarenakan makin turunnya suhu permukaan laut. (Ridha et al., 2013) musim timur memiliki kandungan klorofil lebih tinggi dikarenakan terjadinya upwelling di samudera Hindia.

distribusi konsentrasi klorofil-a pada

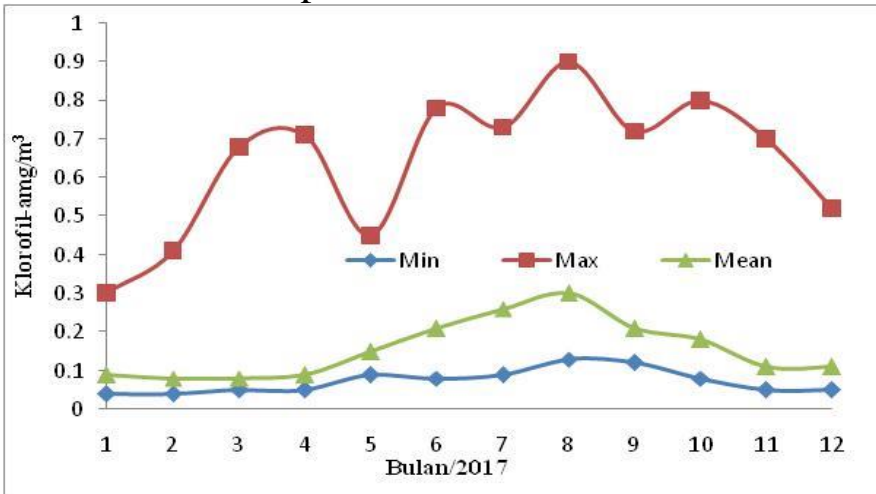

Gambar 2. Klorofila-a periode Bulan Januari - Desember Tahun 2017 di Perairan Samudera Hindia Bagian Timur

\section{Suhu Permukaan Laut (SPL)}

Hasil analisis menunjukan sepanjang tahun 2017 SPL tertinggi terjadi pada bulan November yaitu $31.12^{\circ} \mathrm{C}$ dengan rata-rata SPL $29.84^{\circ} \mathrm{C}$ dan terendah pada bulan Juli $25.22^{\circ} \mathrm{C}$ dengan rata-rata $\mathrm{SPL} 27.53^{\circ}$
C,minimnya suhu pada bulan Juli dan Agustus di karenakan terjadinya upwelling pada bulan tersebut. Menariknya pada bulan Maret rata - rata suhunya tertinggi yaitu $30.12^{\circ} \mathrm{C}$ suhu terendahnya $29.33^{\circ} \mathrm{C}$ 
dan tertingginya $30.17^{\circ} \mathrm{C}$ Data distribusi SPL disajikan pada Gambar 3.

Dari hasil analisa yang ada hal ini disebabkan oleh pergerakan tahunan bumi yang mana pada bulan November dan Desember daerah penelitian ini merupakan titik puncak pergerakan bumi ke utara sehingga mendekati titik fokus sinar matahari dan mengakibatkan tingginya suhu permukaan laut pada bulan November dan Desember. SPL merupakan komponen penting yang dapat mengendalikan cuaca sedangkan (Habibie and Nuraini, 2014) menyatakan karakteristik SPL sangan berpengaruh pada monsun.

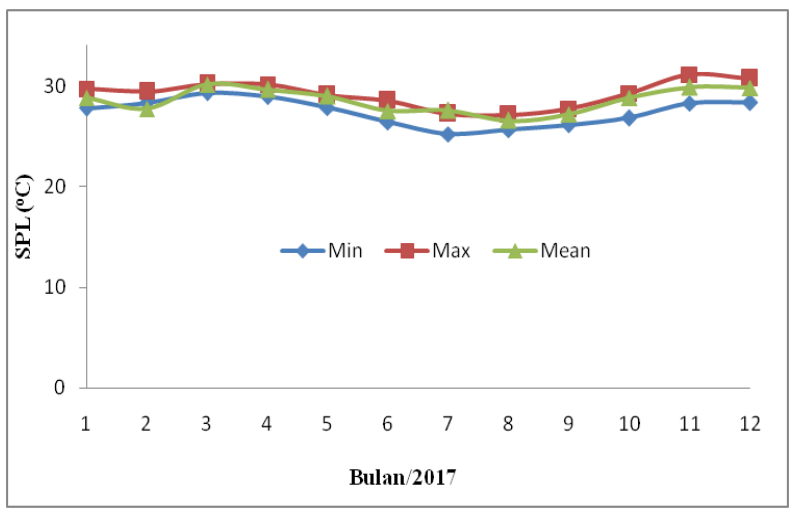

Gambar 3. SPL periode Bulan Januari - Desember Tahun 2017 di Perairan Samudera Hindia Bagian Timur

\section{Sea Level Anomali (SLA)}

Hasil analisa pada perairan Samudera Hindia bagian timur dan sekitarnya anomali tinggi paras laut tertinggi terjadi pada bulan Oktober 2017 yaitu $-0.47 \mathrm{~cm}$ sampai dengan $0.35 \mathrm{~cm}$ dan rata - ratanya adalah $0.04 \mathrm{~cm}$ sedangkan terendah yaitu -0.13 $\mathrm{cm}$ sampai dengan $0.19 \mathrm{~cm}$ dengan rata rata paras lautnya adalah $0.02 \mathrm{~cm}$ dapat dilihat pada Gambar 4. Curah hujan sangat berpengaruh pada anomaly dimana ketika terjadinya peningkatan suhu permukaan laut (anomali posistif), curah hujan di Jawa meningkat sedangkan jika terjadi anomali negative curah hujan di laut Jawa akan menurun. Anomali dilaut Jawa sangat di pengaruhi oleh Samudera Pasifik dan Samudera Hindia terjadi pada bulan pada bulan September - November (Mulyana, 2000).

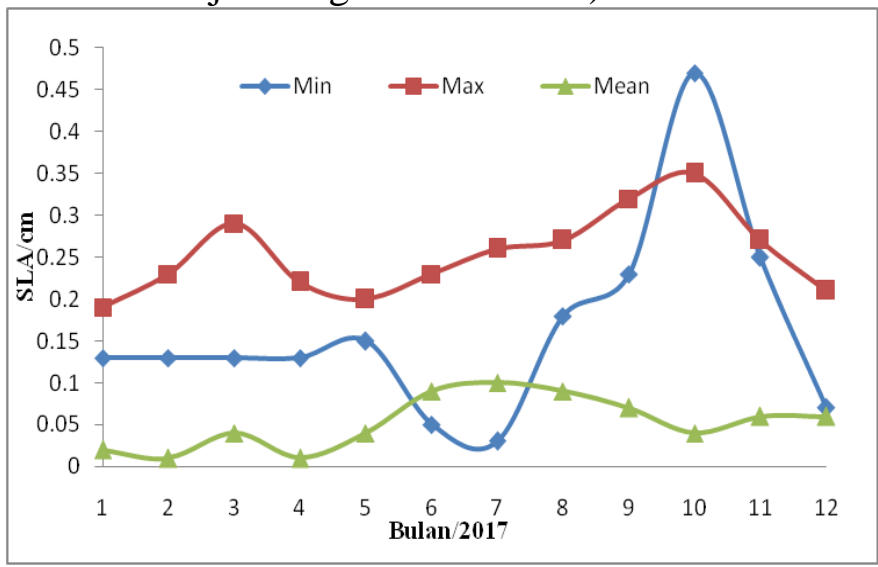

Gambar 4. SLA periode Bulan Januari - Desember Tahun 2017 di Perairan Samudera Hindia Bagian Timur. 
Energi Kinetik (Eddies)

Arus yang yang di konversikan menjadi Energi Kinetik (Eddies) puncaknya

terjadi pada bulan maret yaitu 1.35 dan terendah pada bulan November yaitu 0.97.dapat dilihat pada Gambar 5

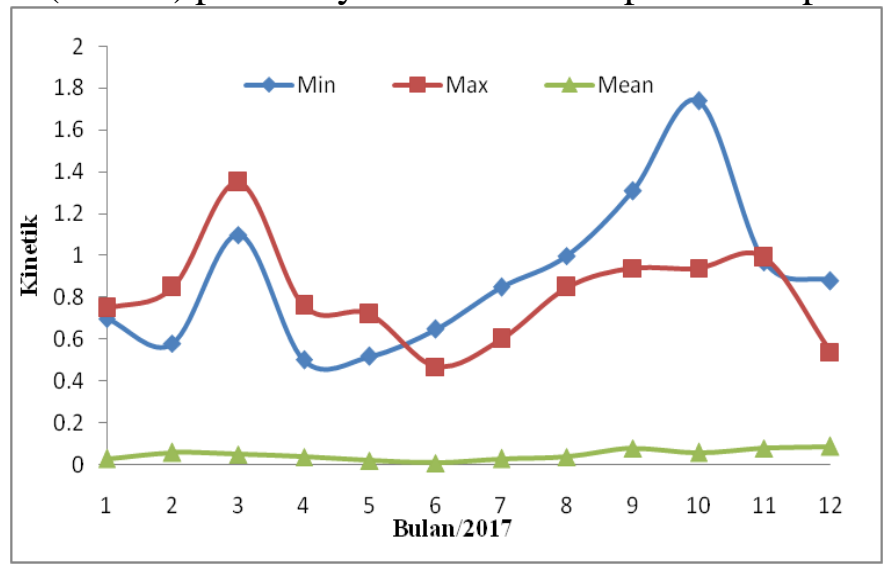

Gambar 5. Energi Kinetik periode Bulan Januari - Desember Tahun 2017 di Perairan Samudera Hindia Bagian Timur

\section{Daerah penangkapan Tuna Long Line} sepanjang tahun 2017.

Umumnya kapal Tuna Long Line yang beroperasi di timur samudera Hindia adalah kapal - kapal berbendera Jepang dan Indonesia. Pergerakan kapal tersebut di unduh melalui website https://globalfishingwatch.org/map/?locale =en Global Fishing Watch. Pada umumnya mulai dari bulan Januari sampai dengan Desember 2017 konsentrasi pergerakan kapal dalam melakukan operasi penangkapan terkonsentrasi pada $11-15^{\circ}$ LS dan $113-120^{\circ}$ BT dan separuh dari kapal-kapal tersebut berada dalam wilayah pengelolaan perikanan Negara Repubik Indonesia (WPP - NRI ) 573 Gambar 6. 


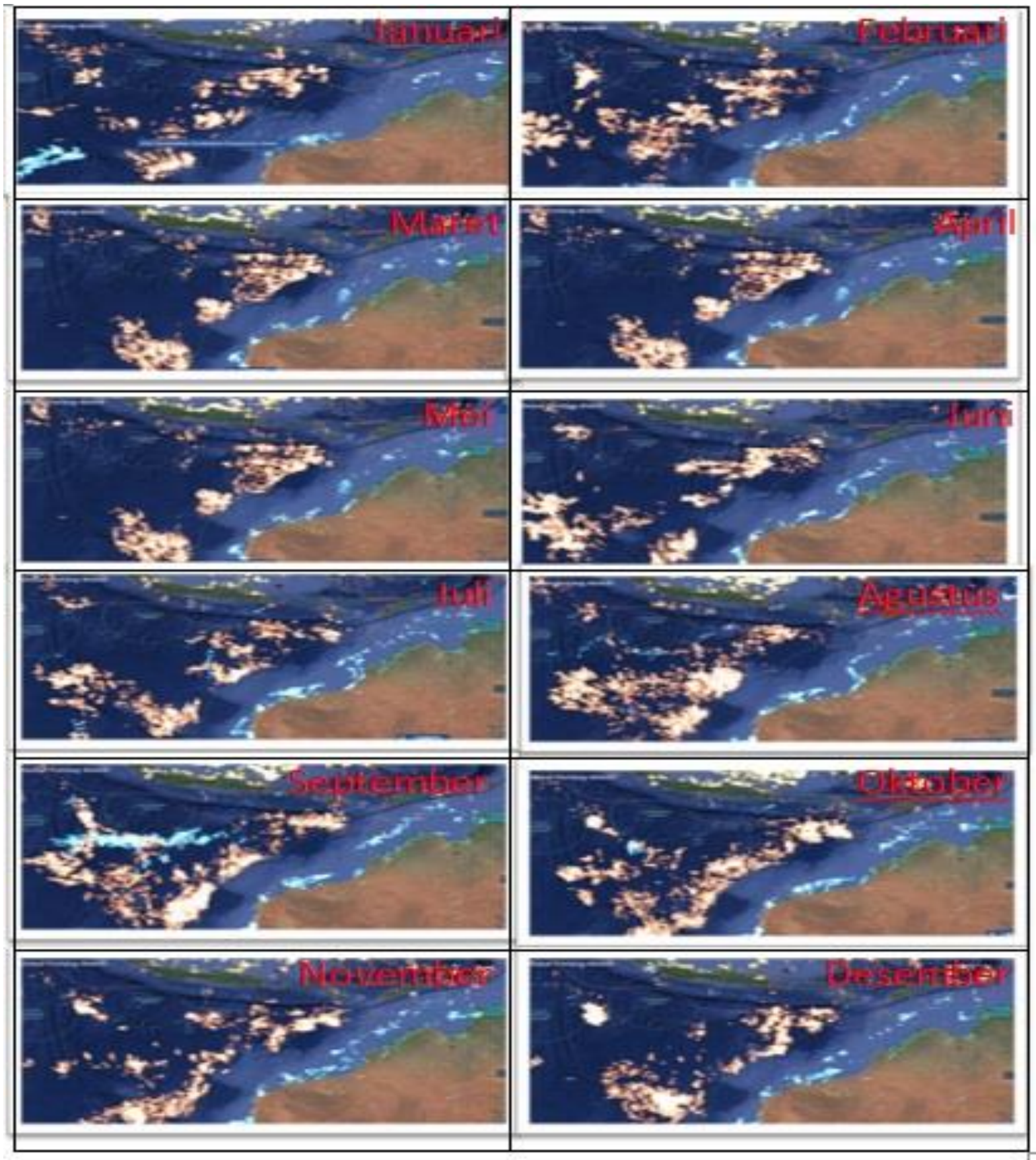

Gambar 6. Lokasi penangkapan tuna long line ( Indonesia dan Jepang) tahun 2017 di Samudera Hindia bagian Timur

\section{Daerah Penangkapan Ikan}

Dilihat dari data Global Fishing World operasi penangkapan pada daerah penelitian menyebar, namun terkonsentrasi pada $11-15^{\circ} \mathrm{LS}$ dan $113-120^{\circ} \mathrm{BT}$ hal ini dapat dilihat pada gambar 2 titik penangkapan dan data Global Fishing World. Overlay fishing ground tuna long line dengan parameter oseanografi dapat dilihat pada Gambar 7, 8, 9 dan 10. 

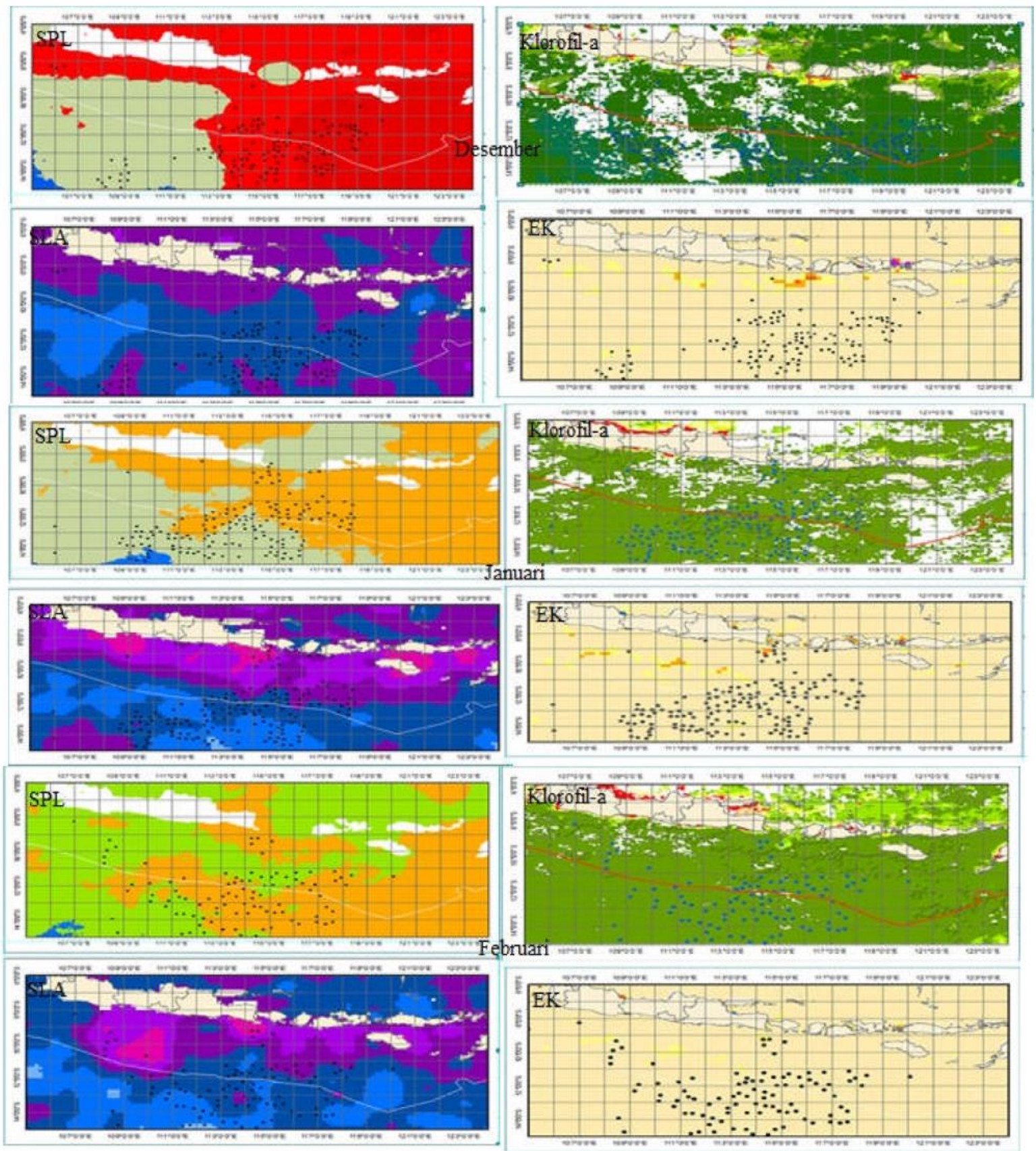

Gambar 7. Overlay fishing ground tuna long line dengan parameter oseanografi musim barat 

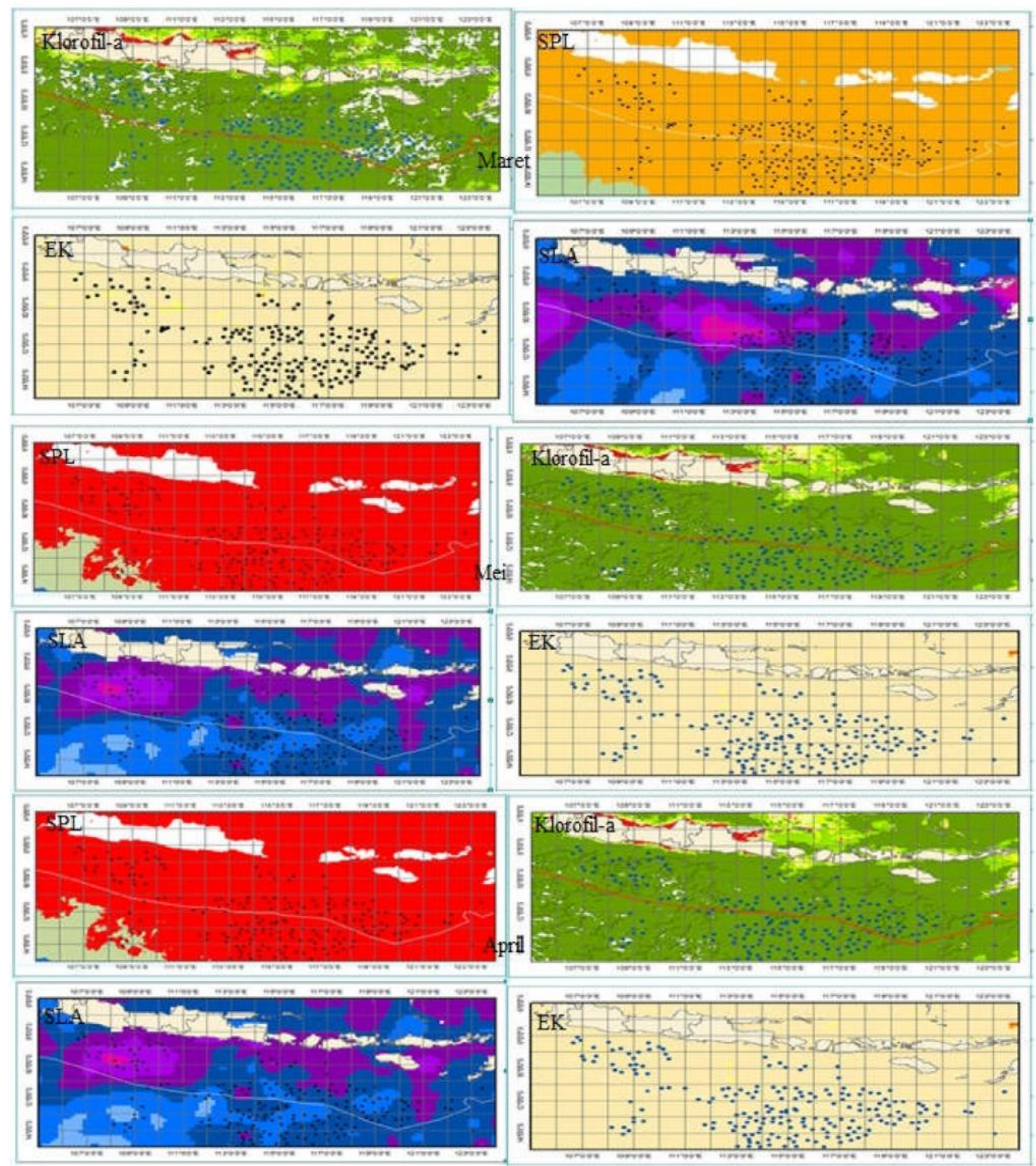

Gambar 8. Overlay fishing ground tuna long line dengan parameter oseanografi musim peralihan barat timur 

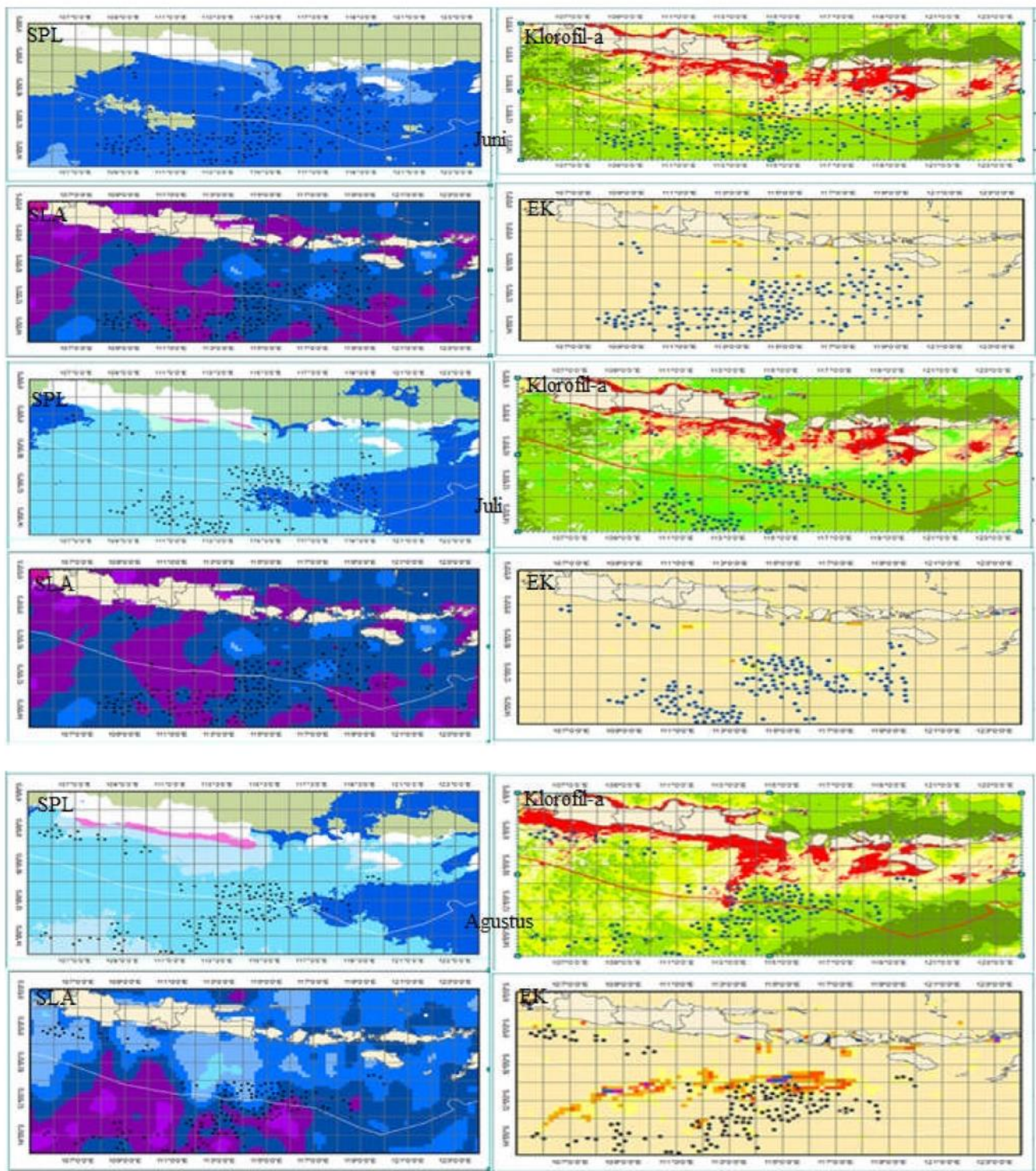

Gambar 9. Overlay fishing ground tuna long line dengan parameter oseanografi musim timur 


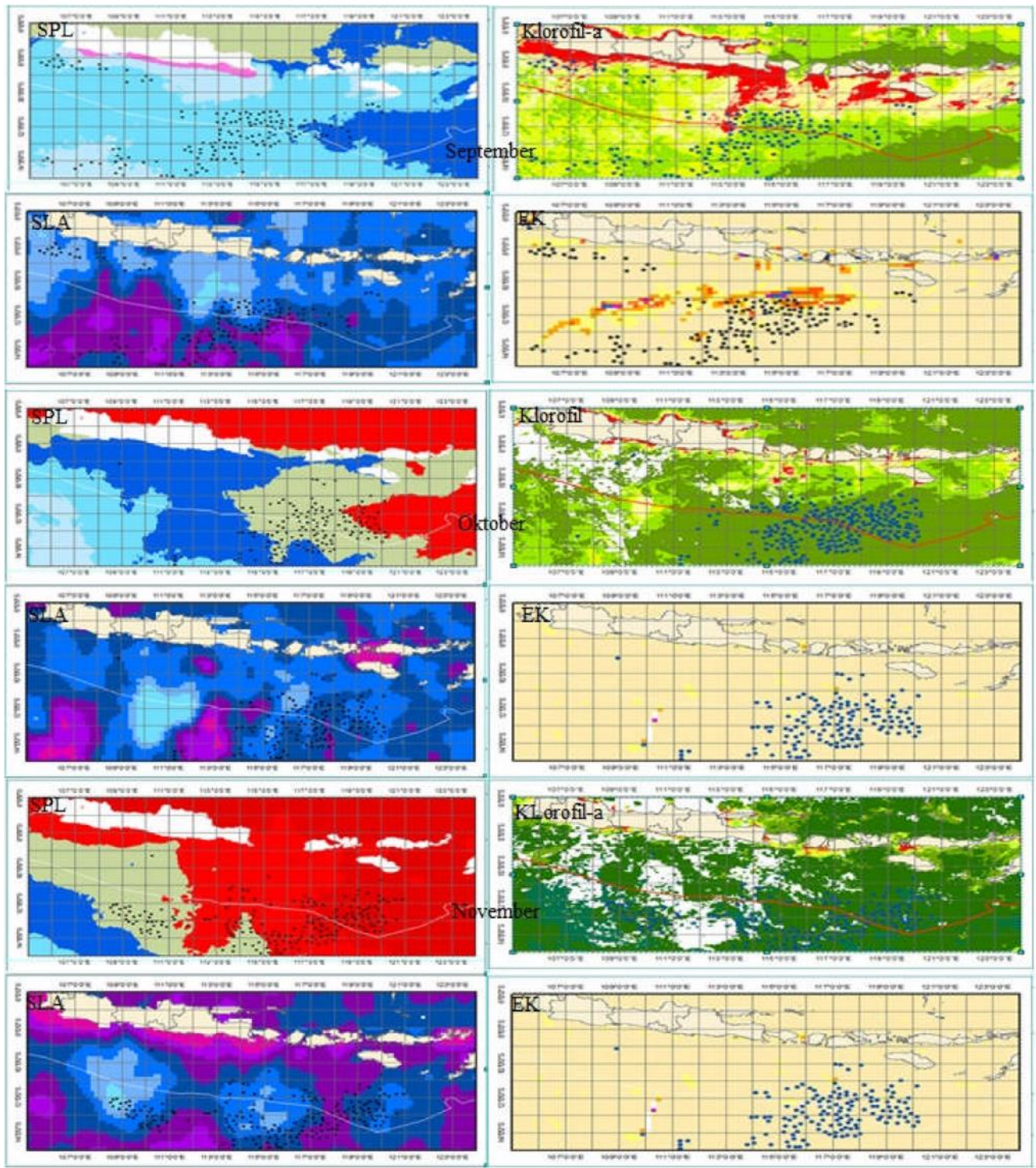

Gambar 10. Overlay fishing ground tuna long line dengan parameter oseanografi musim peralihan timur barat

\section{Oseanografi Penangkapan dan Kehadiran Tuna}

Konsentrasi penangkapan tuna sepanjang tahun 2017 pada $11-15^{\circ} \mathrm{LS}$ dan $113-120^{\circ}$ BT yang mana hasil distribusi vertikal Global Marine Atlas Argo Temperatur pada $112^{\circ}$ BT antara 8.6-14.5 LS menunjukan terjadinya tekanan masa air ke permukaan (upwelling) pada bulan Juli sampai dengan Agustus 2017, sampai ke 
permukaan hingga suhu $26^{\circ} \mathrm{C}$ yang puncaknya pada bulan Agustus dan terlihat tingginya kolofil-a pada bulan Agustus. Menurut Bahtiar et al., (2011) pada Samudera Hindia swimming layer tuna albakora (thunus alalunga) $85.73-24.74 \mathrm{M}$ dengan suhu $21.41-26.40^{\circ} \mathrm{C}$ demikian juga Pranata et al., (2013) swimming layer tuna albakora (thunus alalunga) $64-232 \mathrm{M}$.

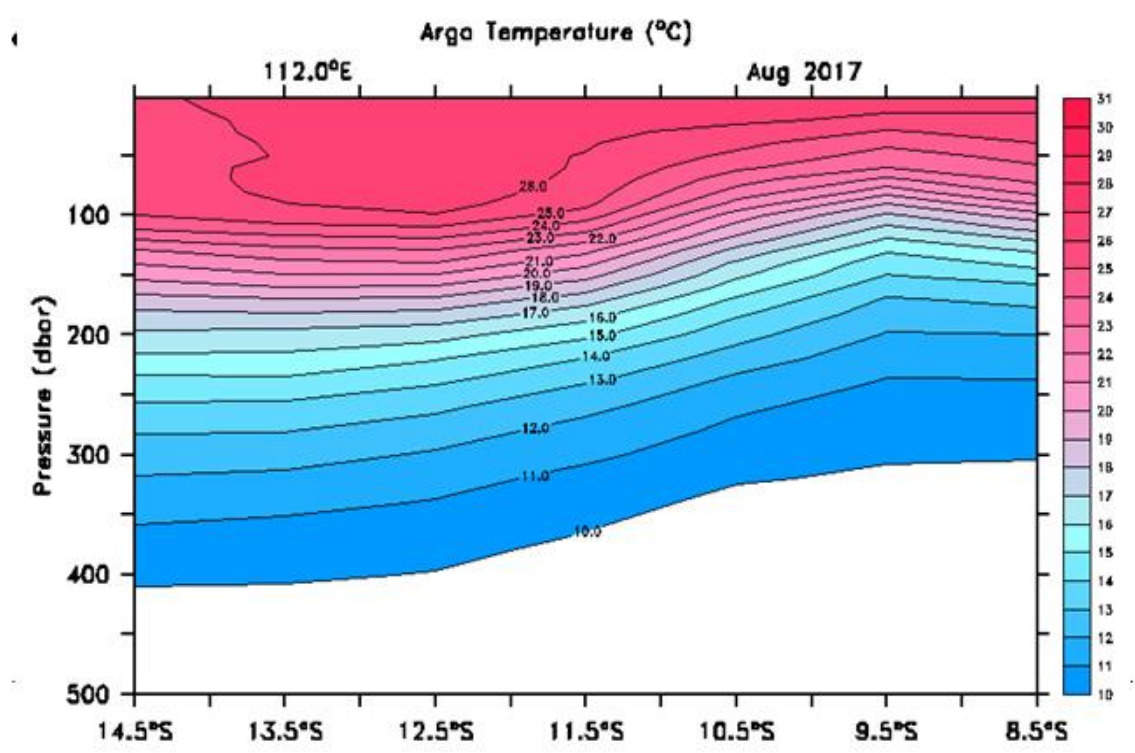

Gambar 11. Distribusi Vertikal Suhu Kolom Air

Dari hasil analisa terkonsentrasinya penangkapan pada $11-15^{\circ}$ LS dan $113-$ $120^{\circ}$ BT akibat terjadinya upwelling pada daerah ini,di mana pada suhu kolom air pada kedalaman $40-300 \mathrm{M}$ adalah $12-22^{\circ} \mathrm{C}$ dapat dilihat pada data-data suhu kolom air pada tabel (1).

Tabel 1. Suhu Kolom Air dari Januari - Desember 2017

\begin{tabular}{ccc}
\hline Kedalaman $(\mathbf{m})$ & Suhu $\left({ }^{\circ} \mathbf{C}\right)$ & Bulan Sampai Permukaan \\
\hline $30<$ & 29 & Sepanjang tahun \\
50 & 28 & Novemver, Desember, Januari dan Februari \\
$30-80$ & 27 & Juni \\
$40-90$ & 26 & Juli, Agustus, dan September \\
$50-100$ & 25 & - \\
$60-110$ & 24 & - \\
$70-110$ & 23 & - \\
$40-140$ & 22 & - \\
$45-150$ & 21 & - \\
$130-250$ & $15-20$ & - \\
$200-300$ & $12-14$ & \\
\hline
\end{tabular}




\section{KESIMPULAN}

Terkonsentrasinya

Penangkapan

armada tuna Long line Indonesia dan Jepang sepanjang tahun 2017 pada 11$15^{\circ}$ LS dan $113-120^{\circ}$ BT diakibatkan adanya upwelling yang dibuktikan dengan tingginya klorofil-a dan rendahnya SPL pada bulan Juli - Agustus serta kenaikan paras laut dan eddies pada bulan Agustus hingga Oktober dengan kedalaman 40-300 $\mathrm{M}$, dengan Suhu $12-22^{\circ} \mathrm{C}$ sebagai penciri kehadiran tuna pada samudera Hindia.

\section{DAFTAR PUSTAKA}

Acha, Eduardo Marcelo, Alberto Piola, Oscar Iribarne, and Hermes Mianzan. 2015. Ecological Processes at Marine Fronts: Oases in the Ocean. Springer.

Arikunto, Suharsimi. 2019. Prosedur Penelitian. Jakarta: Rineka Cipta.

Bahri, Samsul, Domu Simbolon, and Mustaruddin Mustaruddin. 2017. "Analisis Daerah Penangkapan Ikan Madidihang (Thunnus Albacares) Berdasarkan Suhu Permukaan Laut Dan Sebaran Klorofil-a Di Perairan Provinsi Aceh." Jurnal Teknologi Perikanan Dan Kelautan 8(1):95104.

Gaol, Jonson Lumban, and Bambang Sadhotomo. 2017. "Karakteristik Dan Variabilitas ParameterParameter Oseanografi Laut Jawa Hubungannya Dengan Distribusi Hasil Tangkapan Ikan." Jurnal Penelitian Perikanan Indonesia 13(3):201-211.

Habibie, Muhammad Najib, and Tri Astuti Nuraini. 2014. "Karakteristik Dan Tren Perubahan Suhu Permukaan Laut Di Indonesia Periode 1982-
2009.” Jurnal Meteorologi Dan Geofisika 15(1).

IRI/LDEO Climate Data Library https://iridl.ldeo.columbia.edu/ [dwonload: Januari 2017]

KEPMEN-KP No.107. 2015. Tentang rencana pengelolaan perikanan Tuna cakalang dan tongkol. [diuduh; Januari 2020]

Krauss, Robert M., and Peter D. Bricker. 1967. "Effects of Transmission Delay and Access Delay on the Efficiency of Verbal Communication." The Journal of the Acoustical Society of America 41(2):286-292.

Kunarso, Kunarso, Safwan Hadi, Nining Sari Ningsih, and Mulyono S. Baskoro. 2011. "Variabilitas Suhu Dan Klorofil-a Di Daerah Upwelling Pada Variasi Kejadian ENSO Dan IOD Di Perairan Selatan Jawa Sampai Timor." ILMU KELAUTAN: Indonesian Journal of Marine Sciences 16(3):171-180.

Laurs, R. Michael, Paul C. Fiedler, and Donald R. Montgomery. 1984. "Albacore Tuna Catch Distributions Relative to Environmental Features Observed from Satellites." Deep Sea Research Part A. Oceanographic Research Papers 31(9):1085-1099.

Le Bouteiller, Aubert, Jean Blanchot, and Martine Rodier. 1992. "Size Distribution Patterns of Phytoplankton in the Western Pacific: Towards a Generalization for the Tropical Open Ocean." Deep Sea Research Part A. Oceanographic Research Papers 39(5):805-823. 
Mackey, David C. 1995. "Method and Device for Acute Pain Management by Simultaneous Spinal Cord Electrical Stimulation and Drug Infusion."

Mulyana, Erwin. 2000. "Hubungan Antara Anomali Suhu Permukaan Laut Dengan Curah Hujan Di Jawa." Jurnal Sains \& Teknologi Modifikasi Cuaca 1(2):125-132.

Ridha, Urfan, Agus Hartoko, and Max Rudolf Muskanonfola. 2013. "Analisa Sebaran Tangkapan Ikan Lemuru (Sardinella Lemuru) Berdasarkan Data Satelit Suhu Permukaan Laut Dan Klorofil-a Di Perairan Selat Bali." Management of Aquatic Resources Journal 2(4):53-60.
Sarianto, Deni. 2018. "Analisis Daerah Penangkapan Ikan Cakalang (Katsuwonus Pelamis) Di Sekitar Bacan Dan Obi, Halmahera Selatan." SEMAH Jurnal Pengelolaan Sumberdaya Perairan 2(3).

Sarianto, Deni, Domu Simbolon, and Budi Wiryawan. 2017. "Dampak Pertambangan Nikel Terhadap Daerah Penangkapan Ikan Di Perairan Kabupaten Halmahera Timur." Jurnal Ilmu Pertanian Indonesia 21(2):104-113.

Schweitzer, Roland, Robert Simons, Kevin O’Brien, and Eugene Burger. 2018. "Google Charts JSON Data Tables Directly from ERDDAP." 